\title{
Nasopharyngeal tuberculosis detected on imaging
}

\author{
Naohiro Oda (1) , ${ }^{1}$ Takahisa Koyama, ${ }^{2}$ Genyo Ikeda, ${ }^{3}$ Ichiro Takata'
}

${ }^{1}$ Internal Medicine, Fukuyama City Hospital, Fukuyama, Japan ${ }^{2}$ Otorhinolaryngology, Fukuyama City Hospital, Fukuyama, Hiroshima, Japan ${ }^{3}$ Respiratory Medicine, Chugoku Central Hospital, Fukuyama, Hiroshima, Japan

\section{Correspondence to}

Dr Naohiro Oda; dancingqueen1212@hotmail. com

Accepted 27 July 2021
Check for updates

(C) BMJ Publishing Group Limited 2021. No commercial re-use. See rights and permissions. Published by BMJ.

To cite: Oda N, Koyama T, Ikeda $\mathrm{G}$, et al. BMJ Case Rep 2021;14:e245736. doi:10.1136/bcr-2021245736

\section{DESCRIPTION}

A 43-year-old Chinese woman was referred to our hospital because of an abnormal shadow on a chest radiograph. The patient had come to Japan from China 4 weeks previously for technical intern training. She had never smoked and had no medical history of note. She had a mild cough but no fever, fatigue or weight loss. Her complete blood count was normal, and her serum $C$ reactive protein, carcinoembryonic antigen and squamous cell carcinoma-associated antigen levels were not increased. Chest CT showed multiple nodules with calcification in both upper lobes of the lungs (figure 1A). Fluorodeoxyglucose-positron emission tomography (FDG-PET)/CT was performed to rule out malignant tumours and showed pulmonary nodules without FDG uptake (figure 1B) and a nasopharyngeal mass with FDG uptake (figure 1C,D). An interferon-gamma release assay (T-SPOT.TB, Oxford Immunotec) was positive. Sputum-smear microscopy, mycobacterial sputum culture and PCR for Mycobacterium tuberculosis in sputum were repeatedly negative.

We diagnosed the pulmonary nodules as old tuberculosis and further examined the nasopharyngeal mass. Endoscopy showed irregular mucosal thickening without ulceration and exudate the nasopharynx (figure 2). A biopsy specimen of the nasopharynx revealed granulomatous inflammation with epithelioid cells and focal necrosis. Ziehl-Neelsen staining of the biopsy specimen showed 1-2 acid-fast bacteria per 300 fields (1000x magnification) and PCR for M. tuberculosis was negative. Four weeks later, M. tuberculosis was detected in a culture of the biopsy specimen. Therefore, the patient was diagnosed with nasopharyngeal tuberculosis. The strain of M. tuberculosis was drug sensitive. The patient was given antituberculous

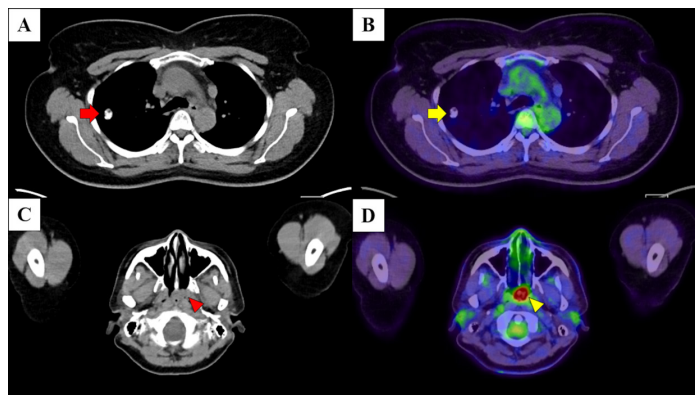

Figure 1 Chest $\mathrm{CT}$ showing multiple nodules with calcification in both upper lobes of the lung (A). Fluorodeoxyglucose (FDG)-positron emission tomography/ CT showing pulmonary nodules without FDG uptake (B) and a nasopharyngeal tumour with FDG uptake (C, D).

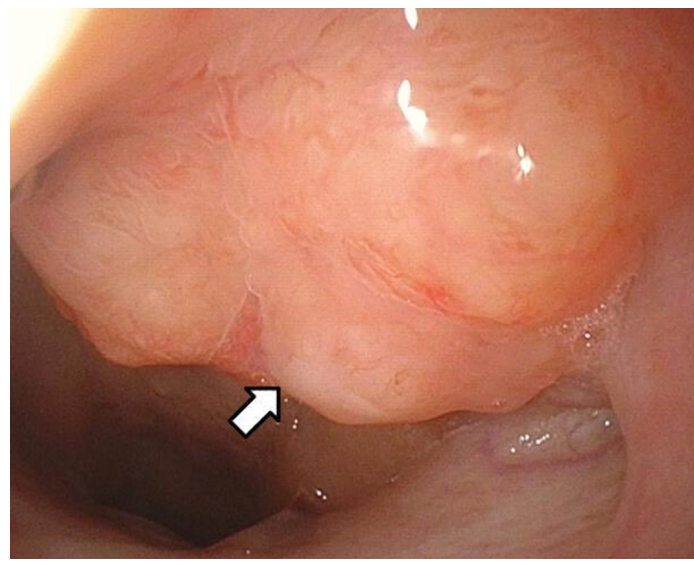

Figure 2 Irregular mucosal thickening is present in the nasopharynx.

treatment with rifampicin, isoniazid, pyrazinamide and ethambutol for 2 months, followed by rifampicin and isoniazid for 4 months.

Today, nasopharyngeal tuberculosis is a rare form of extrapulmonary tuberculosis in both tuberculosis-endemic and non-endemic areas. ${ }^{1}{ }^{2}$ Nasopharyngeal tuberculosis usually occurs secondary to pulmonary tuberculosis. When treatment-naïve old tuberculosis is detected, nasopharyngeal tuberculosis should be considered in the differential diagnosis of nasopharyngeal tumours. Nasopharyngeal tuberculosis may be overlooked because it is often asymptomatic unless complicated by pulmonary tuberculosis, and the nasopharynx is a difficult site to observe without endoscopy. The ability of FDG-PET/CT to detect extrapulmonary tuberculosis is very high. FDG-PET/CT can also be useful in distinguishing old and active tuberculous lesions and in determining the effects of tuberculosis treatment. ${ }^{3}$ This case illustrates the usefulness of nuclear medicine imaging in the diagnosis of nasopharyngeal tuberculosis, a rare form of extrapulmonary tuberculosis.

\section{Learning points}

- Today, nasopharyngeal tuberculosis is a rare form of extrapulmonary tuberculosis in both tuberculosis-endemic and non-endemic areas.

- This case illustrates the utility of fluorodeoxyglucose-positron emission tomography/computed tomography for detecting nasopharyngeal lesions, including nasopharyngeal tuberculosis, especially asymptomatic cases.

Contributors NO and TK performed diagnostic tests; GI was responsible for patient care; NO and IT drafted the manuscript; all 
authors critically revised the report, commented on a draft of the manuscript and approved the final report.

Funding The authors have not declared a specific grant for this research from any funding agency in the public, commercial or not-for-profit sectors.

Competing interests None declared.

Patient consent for publication Obtained.

Provenance and peer review Not commissioned; externally peer reviewed.

\section{REFERENCES}

1 Pang Y, An J, Shu W, et al. Epidemiology of extrapulmonary tuberculosis among inpatients, China, 2008-2017. Emerg Infect Dis 2019;25:457-64.

2 Peto HM, Pratt RH, Harrington TA, et al. Epidemiology of extrapulmonary tuberculosis in the United States, 1993-2006. Clin Infect Dis 2009;49:1350-7.

3 Bomanji J, Sharma R, Mittal BR, et al. PET/CT features of extrapulmonary tuberculosis at first clinical presentation: a cross-sectional observational ${ }^{18} \mathrm{~F}$ FDG imaging study across six countries. Eur Respir J 2020;55:1901959.

\section{ORCID iD}

Naohiro Oda http://orcid.org/0000-0001-8112-9233

Copyright 2021 BMJ Publishing Group. All rights reserved. For permission to reuse any of this content visit

https://www.bmj.com/company/products-services/rights-and-licensing/permissions/

BMJ Case Report Fellows may re-use this article for personal use and teaching without any further permission.

Become a Fellow of BMJ Case Reports today and you can:

- Submit as many cases as you like

- Enjoy fast sympathetic peer review and rapid publication of accepted articles

- Access all the published articles

Re-use any of the published material for personal use and teaching without further permission

\section{Customer Service}

If you have any further queries about your subscription, please contact our customer services team on +44 (0) 2071111105 or via email at support@bmj.com.

Visit casereports.bmj.com for more articles like this and to become a Fellow 